\title{
広帯域性の変動風力を受ける弾塑性構造物の応答変位振幅の確率分布 PROBABILITY DISTRIBUTION FUNCTION OF RESPONSE AMPLITUDE FOR AN ELASTO-PLASTIC STRUCTURE SUBJECTED TO WIDE-BAND FLUCTUATING WIND FORCE
}

\author{
吉江慶祐*, 大熊武司**, 北村春幸***, 和田 章**** \\ Keisuke YOSHIE, Takeshi OHKUMA, Haruyuki KITAMURA \\ and Akira WADA
}

\begin{abstract}
This study is the first step of the development of the prediction technique for wide-band random response of a structure subjected to fluctuating wind force. The authors have presented a prediction method of fluctuating wind-force induced an elasto-plastic response based on energy balance, and showed its validity. However, the method was limited to the case of a narrow-band random process. Therefore, it is necessary to expand the method to the case of a wide-band random process in order to make the method more practical. This paper presents a prediction model of a probability density function of an elasto-plastic response displacement amplitude of a structure subjected to fluctuating wind-force, and, in turn, investigates the validity of the model.
\end{abstract}

Keywords: wind force, stationary random process, wide-band process, probability density function, elasto-plastic response 風外力, 定常ランダム過程, 広带域性, 確率密度関数, 弾塑性応答

1. 序

筆者らは既報り「エネルギーの釣合に基づく変動風力を受ける弾 塑性構造物の応答予測手法」において, 風直交方向応答のような平 均風力がゼロで構造物の固有振動数成分応答が卓越する場合につい て，エネルギーの釣合いに基づいて，時刻歴応答解析を用いずに弾 塑性構造物の応答予浿が可能であることを示した。提案手法は，構 造物の応答変位の $\mathrm{ms}$ 值と塑性率の関係を, 基本的な定常ランダ 么応答の性質をモデ化して応答变位 $\mathrm{rms}$ 值 - 塑性率の期待値の理 論解を用いて導いており，信頼性と一般性の高い手法であると考え る。また, エネルギーの釣合から直接的に弾塑性沁答量を評価する ことが可能であり, 変動風力による入力エネルギ一量と構造物の降 伏変形・降伏せん断力と塑性変形最が直接関係づけられることで, 変動風力下での構造物の弾塑性設計の信頼性を確保することが可能 になるものと思われる。

しかし，弾塑性構造物の風応答予測を実用化するためには，風方 向風力のような平均風力を含み, かつ低振動数成分を中心に広帯域 にパワーを有する変動風力に対する応答予測手法も必要であり, 重 要となる。

既報1で指摘したように, 変位侬存型の履歴特性を有する履歴 減衰型の構造物の弾塑性性状を捉えるためには最大応答值の他に, ピーク・ピーク変位振幅のような全振幅を求める必要がある。乙か し, 弾性応答の場合について定常ランダム過程の振幅の極大值また
は極小值の確率分布が明らかになっている刚えば2)、3)以外は, 構造物 の応答の全振幅を対象とした研究はほとんど見られない。 本研究は，エネルギーの釣合いに基つくく弾塑性構造物の広帯城な 風店答予測手法の開発の第 1 段階として，平均值がゼロの広带域性 の変動風力を受ける弾塑性構造物の応答変位振幅の確率密度関数の 予㲘手法を検討し，その有効性を示すことを目的とする。辻田ら4) は風方向応答のような広带域なランダム结答を，固有振動数より低 振動数成分（準静的成分に相当）と固有振動数付近の成分（共振成 分）に分離して，それぞ別々に応答を語価することで，応答予㑚 が可能であることを示している。本研究も辻田らの研究を参考にし て，構造物の広带域な弹塑性風応答を準静的成分と共振成分に分離 し，各々ならびに両者の組み合わせとして応答性状の分析を行い， 広带域なランダム応答变位振幅の確率密度関数の予測方法を提案す る。さらに, 提案手法により広帯域な弾塑性風応答の履歴吸収工ネ ルギーを評価し，時刻歴応答解析結果と比較することで提案手法の 有効性を確認する。

\section{2. 検討に用いる变動風力の特性}

本研究は, 振動系の固有振動数よりも低振動数側にもパワーを有 する外乱に対する応答を検討の対象にしている。減衰の小さな振動 系の場合であっても, 固有振動数より低い振動数範囲での変位応答 倍率はほぼ 1 であるので，低振動数領域での応答特性は，外乱の特

\footnotetext{
* 睏日建設計構造設計室 主管, 東京工業大学 大学院博士課程 (杜会人プログラム)・工修

** 种奈川大学工学部建築学科教授・工傅

****東京理科大学理工学部建榮学科教授. 博士 (工学)

**** 東京工業大学建築物理研究センター 教授・工博
}

Senior Structural Engineer, Structural Engineering Dept., Nikken Sekkei Ltd., Graduate Student, Tokyo Institute of Technology, M. Eng.

Prof., Dept. of Architecture, Faculty of Engineering, Kanagawa University, Dr. Eng. Prof., Dept. of Architecture, Faculty of Science and Technology, Tokyo University of Science, Dr. Eng.

Prof., Structural Engineering Research Center, Tokyo Institute of Technology, Dr. Eng. 


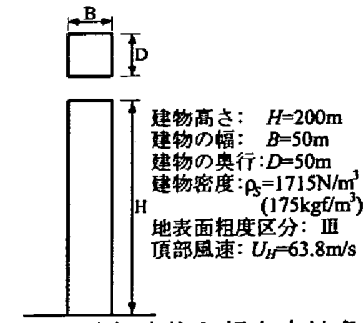

图 1 対象建物と想定立地条件

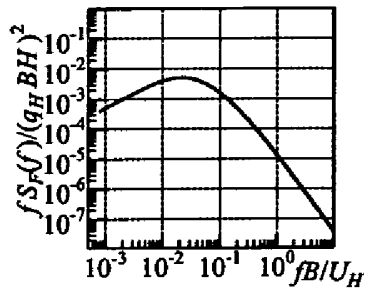

图 3 変動風力のパワースペクトル密度

性そのものが表れる。以下の檢討で，定常ランダム外乱を受ける 振動系の定常応答の統計的性質を, 時刻歴応答解析を用いたモンテ カルロシミュレーションを用いて検証するため，検討に用いる外乱 の特性を明らかにする必要がある。ここでは, 検討に用いる模擬風 力波形の作成方法について示し，模擬風力波形の振幅特性について 検討する。なお本論文では,「時刻歴応答解析の結果」は時刻原応答 解析を用いたモンテカルロシミュレーションによる応答結果の確率 統計的な評価結果をさすものとする。

本研究の検討に用いる解析モテルは, 図 1 に示す建物を対象と し，1次モードの風応答のみに注目し（弾塑性系については塑性化 後も建物の振動モードに変化が生じないと仮定），水平 1 自由度の 1 質点系モテルとする。解析モテルの質量 $m$ と外力 $F$ は，建物の 1 次モードを頂部が 1 の直線モードとした時のモーダル質量とモー ダル外力として与えるものとする (図 2)。弾性甽性 $k$ または復元力 特性 $Q(x)$ は後述する。広带域性の変動風力として, 「建築物荷重指 針・同解説」5)(以下「荷重指針」) による風方向変動風力のパワース ペクトル密度をもとに，模擬風力波形を作成する。図 3 に検討に用 いる変動風力のパワースペクトル密度を示す。図中の $f$ は振動数, $q_{H}$ は建物頂部での速度圧 $\left(q_{H}=1 / 2 \cdot \rho U_{H}{ }^{2}, \rho\right.$ は空気密度 $)$ を示す。 風速は既報1) と同じく頂部風速 $U_{H}=63.8 \mathrm{~m} / \mathrm{s}$ とする。模擬風力波形 は, 変動風力を定常ガウス過程と仮定し, 次式に示す三角級数モデ ル6にによりシミュレートする。

$$
F(t)=\sum_{k=1}^{N}\left\{a_{k} \cdot \cos \left(\omega_{k} \cdot t\right)+b_{k} \cdot \sin \left(\omega_{k} \cdot t\right)\right\}
$$

ただし， $a_{k}, b_{k}$ は平均值 0, 分散 $\sigma_{F}^{2}\left(\omega_{k}\right)=S_{F}\left(\omega_{k}\right) \cdot d \omega$ のガウ ス分布に従うそれぞれ独立な確率変数， $F$ は変動風力， $S_{F}$ は 柗動風力のパワースペクトル密度, $t$ は時間， $\omega$ は円振動数。 模擬風力波形は 1 波形につき 0.1 秒刻みで 16384 ステップ作成する。 なお， $N=16384$, 振動数 $f(=\omega / 2 \pi)$ の範囲は $1 / 1638.4 \sim 1 / 0.1(\mathrm{~Hz})$, 振動数刻み $\Delta f=1 / 1638.4(\mathrm{~Hz})$ とした。(1) 式による模擬風力波形の 先頭はゼロとは限らないため, 過渡応答の影響を減らし定常状態の 評価を行うため，各波形に次式の包絡関数 $A(t)$ を乗じる。

$$
A(t)= \begin{cases}\frac{1}{2}\left(1-\cos \left(\frac{\pi}{T_{s}} t\right)\right) & \left(0 \leqq t<T_{s}\right) \\ 1 & \left(t>T_{s}\right)\end{cases}
$$

ただし， $T_{s}$ は包絡関数の立ち上がり時間 $(50 \mathrm{sec})$ 。

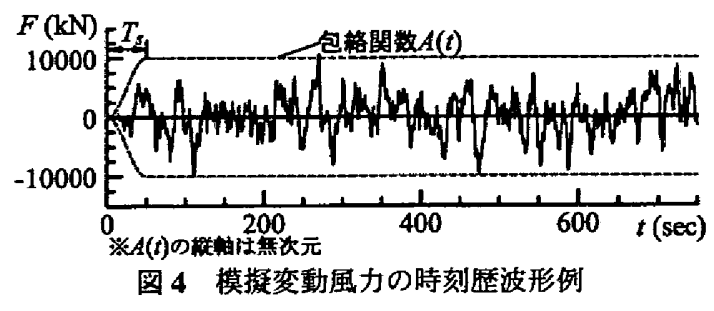

图 4 に模擬風力波形例を示す。各振動数 $\omega_{k}$ 成分がそれぞれガウス 過程なので，その級数和である $F(t)$ もカウス過程であることは明ら かである。また, $F(t)$ からある振動数帯域成分のみを取り出した時 刻歴波形もカウス過程となることも自明である。ここで, 境界周期 $T_{\text {Bound }}$ (または境界振動数 $f_{\text {Bound }}$ ) を設け, $F(t)$ を $f_{\text {Bound }}\left(=1 / T_{\text {Bound }}\right.$ ) より低振動数成分のみを, 後述するフーリエ変換・逆変換を利用し た方法で分離した波形 $F_{L}(t)$ を作成し， $F_{L}(t)$ の極值 $F_{L, p}$ の確率密度 関数 (ここでは極大值の影度分布を全極大值数と振幅の刻み幅で基 潐化したものとする) を求める。パワースペクトル密度が $S_{\xi}(\omega)$ で ある定常カウス過程 $\xi$ の極大值 $\xi_{p}$ の確率密度関数 $p\left(\xi_{p}\right)$ は (3) 式 で与えられる。3) (極大値は, 図 5 に示す正側と負側の極大值)

$$
\begin{aligned}
p\left(\xi_{p}\right) & =\frac{1}{\sqrt{2 \pi} \sigma_{\xi}}\left[\varepsilon \exp \left(-\frac{1}{2} \frac{\xi_{p}^{2}}{\varepsilon^{2} \sigma_{\xi}^{2}}\right)+\right. \\
& \left.\sqrt{1-\varepsilon^{2}} \frac{\xi_{p}}{\sigma_{\xi}} \exp \left(-\frac{\xi_{p}^{2}}{2 \sigma_{\xi}^{2}}\right) \sqrt{\frac{\pi}{2}}\left\{1+\operatorname{erf}\left(\frac{\sqrt{1-\varepsilon^{2}}}{\sqrt{2}} \frac{\xi_{p}}{\varepsilon \sigma_{\xi}}\right)\right\}\right]
\end{aligned}
$$

ただし， $\sigma_{\xi}$ は $\xi$ の標準偏差, $\operatorname{erf}(\tau)$ は誤差関数で次式による。

$$
\operatorname{erf}(\tau)=\frac{2}{\sqrt{\pi}} \int_{0}^{\tau} e^{-t^{2}} d t
$$

また, $\varepsilon$ はパワースペクトル密度の特性を表すパラメータで次式に よる。

$$
\begin{gathered}
\varepsilon=\sqrt{\frac{m_{0} m_{4}-m_{2}^{2}}{m_{0} m_{4}}} \\
m_{j}=\int_{0}^{\infty} \omega^{j} S_{\xi}(\omega) d \omega
\end{gathered}
$$

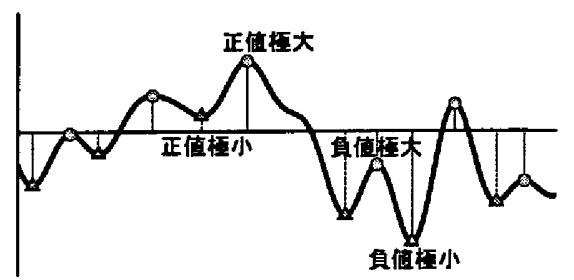

図 5 広帯域ランダム過程の時刻歴波形の模式図

表 1 パワースペクトル密度の形状特性を表すパラメータ $\varepsilon$

\begin{tabular}{c|ccc}
\hline$T_{\text {Bound }}$ & $9 \mathrm{sec}$ & $15 \mathrm{sec}$ & $21 \mathrm{sec}$ \\
\hline$\varepsilon$ & 0.845 & 0.788 & 0.753 \\
\hline \multicolumn{3}{c}{ ただし, } & $U_{H}=63.8 \mathrm{~m} / \mathrm{sec}$
\end{tabular}

図 6 に境界周期 $T_{\text {Bound }}=9 \mathrm{sec}, 15 \mathrm{sec}, 21 \mathrm{sec}$ の時の $F_{L}(t)$ の極大值 $F_{L, p}$ の確染密度関数を示す。図中の曲線は (3) 式による極値分布の理論 值に低振動数成分分離波形 $F_{L}$ の標淮偏差 $\sigma_{F_{L}}$ と変動風力のパワー スペクトル密度 $S_{F}^{\prime \prime}(f)$ を用い, 次式により $m_{j}$ を求め, それを (5) 式 

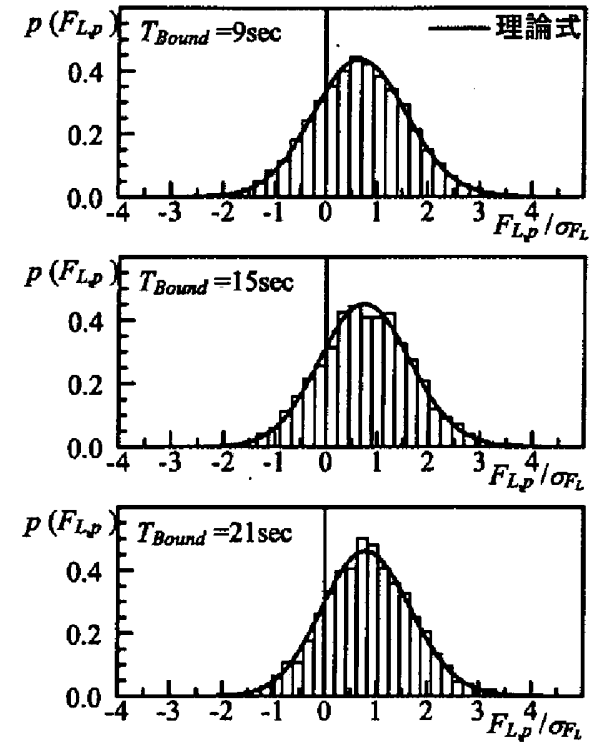

图 6 模擬変動風力波形の低振動成分の極大值確率密度関数

\begin{tabular}{|c|c|}
\hline$T_{0}$ & $3 \mathrm{sec}, 5 \mathrm{sec}, 7 \mathrm{sec}$ \\
\hline$\zeta$ & $0.02,0.10$ \\
\hline
\end{tabular}

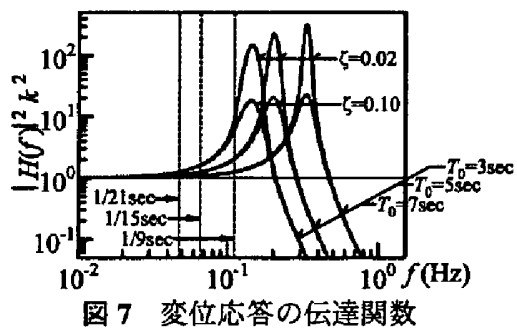

に代入して求めた $\varepsilon$ を用いたものである。用いた $\varepsilon$ を表 1 に示す。

$$
m_{j}=\int_{0}^{f_{\text {Bound }}} 2 \pi(2 \pi f)^{j} S_{F}(f) d f
$$

模擬風力波形の低振動数成分分離波形 $F_{L}(t)$ の極大值分布は (3) 式 とよく一致することが確認できる。(3) 式は，低振動数成分分離波 形の標準偏差 $\sigma_{F_{L}}$ と, パワースペクトル密度から (5),(7) 式を用いて 求まる $\varepsilon$ にって決定され，この $2 \supset$ つ゚ラメータによって外乱の 極大値分布を表すことができることを確認した。

\section{3. 減臺弾性系の応答振幅の確率分布}

はじめに 1 質点減衰弾珄系の時刻歴風応答解析を行い，広帯域亏 ンダム応答時の応答振幅の確率分布について検討する。解析モテル は前章で説明したモデルであり, 解析パラメー夕は固有周期 $T_{0}$, 減 衰定数 ととする。解析パラメー夕を表 2 に示す。前章で説明した模 擬風力波形 (全長 1638.4 秒) 200 個作成し, 解析開始から 400 秒 $\sim 1000$ 秒と， 1000 秒 1600 秒を評価対象とし，評価時間 600 秒の 計 400 サンプルで評価を行う。

構造物の風応答変位の変動成分は, 広帯域定常ランダム過程の低 振動数成分と狭帯域定常ランタム過程の共振成分の和と見なすこと ができる4)。そこで, 応答変位時刻歷波形 $x(t)$ を低振動数成分と共 振成分に分離して以下の検討を進める。応答変位時刻歷波形成分の 分離は, 応答時刻厢波形 $x(t)$ をフーリ工変換し, 得られたフーリエ スペクトルを境界振動数 $f_{\text {Bound }}=1 / T_{\text {Bound }}$ （ $T_{\text {Bound }}$ は境界周期 $(\mathrm{sec})$ とする）を境に低振動数成分と高振動数成分に分離し，それぞれの フーリエスペクトルを逆フーリエ変換することにより行う。境界周 期として振動系の固有周期から十分に離れて長い周期を選べば，低

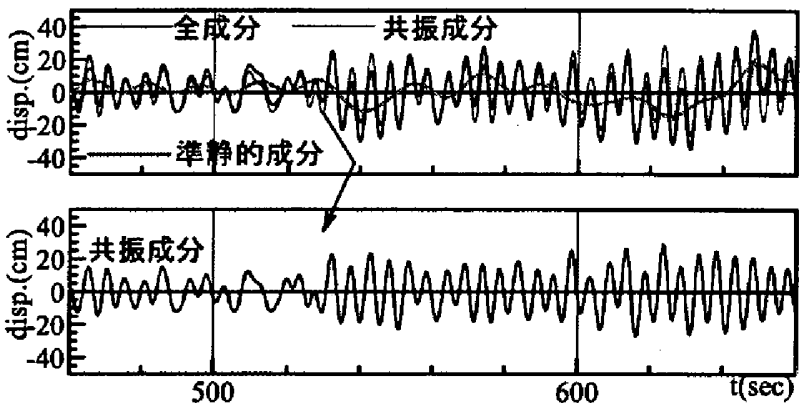

图 8 変位応答時刻歴波形例 $\left(T_{0}=5 \mathrm{sec}, \zeta=0.02\right)$

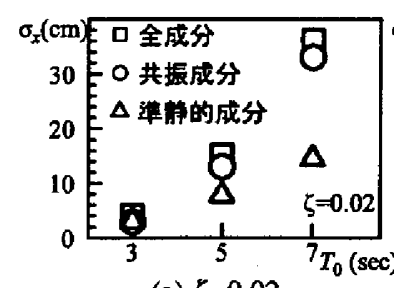

(a) $\zeta=0.02$

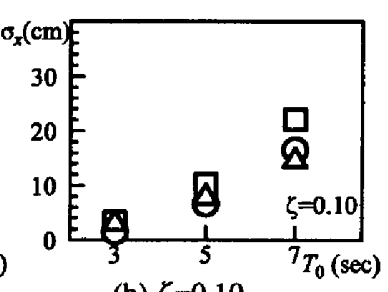

(b) $\zeta=0.10$ 图 9 応答変位 $\mathrm{rms}$ 值

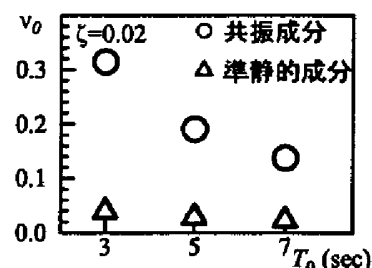

(a) $\zeta=0.02$

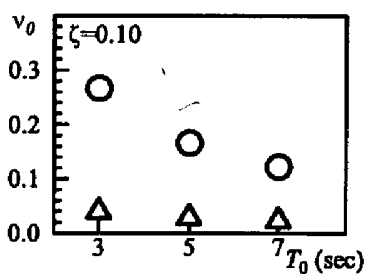

(b) $\zeta=0.10$
振動数成分は外乱による強制振動が，高振動数成分は構造物の共振 成分がそれそれ支配的となる応答を示すと考えられる。以後，低振 動数成分を準静的成分 (添字 $B$ で表す), 高振動数成分を共振成分 (添字 $R$ で表す) とする。図 7 に入力した模擬風力波形之応答変位か ら求めた资位応答の后達関数を示す。伝達関数からほぼ共振の影斐 のなくなる固有振動数の $1 / 3$ の振動数 (固有周期の 3 倍の周期) を境 界振動数 (境界周期) とする。

図 8 に応答変位の時刻歴波形と準静的成分と共振成分の分離波形 の例を示す。図の上段は全成分に準静的成分，共振成分を重好て， 下段は共振成分だけを取り出して示してある。共振成分は平均変位 であるゼロを交差する間に極值がほぼ 1 回だけ現れており，狭帯域 な応答となっていることが確認できる。これに対して，準静的成分 はセ゚ロを交差する間に極值が複数回現れており広帯域な応答となっ ている。

図 9 に応答変位の全成分，共振成分および準静的成分の標準偏 差 $(\mathrm{rms})$ を, 図 10 に応答変位の共振成分および淮静的成分のゼロ クロッシング数 $v_{0}$ を示す。共振成分の応答変位 rms 值は固有周期, 減衰定数の変化とともに㚆化しているが，淮静的成分は減衰定数に よりほとんど変化していない。これは，準静的成分が外乱に支配さ れ，構造物の振動特性の影響が小さいことによると考えられる。

図 11 に変位応答波形の例を示し, 以降の考察に用いる極大・極 小值の定義を示す。図 11 上段に全成分応答波形を, 中段・下段に 準静的成分波形と共振成分波形をそれぞれ示す。上段の灰色の実楾 は準静的成分波形である。図 11 中段, 下段に示すように準静的成 分波形，共振成分波形がゼロを正勾配で公差する周期をそれぞれ準 静的成分拉よび共振成分のゼロクロスサイクルとする。準静的成分 


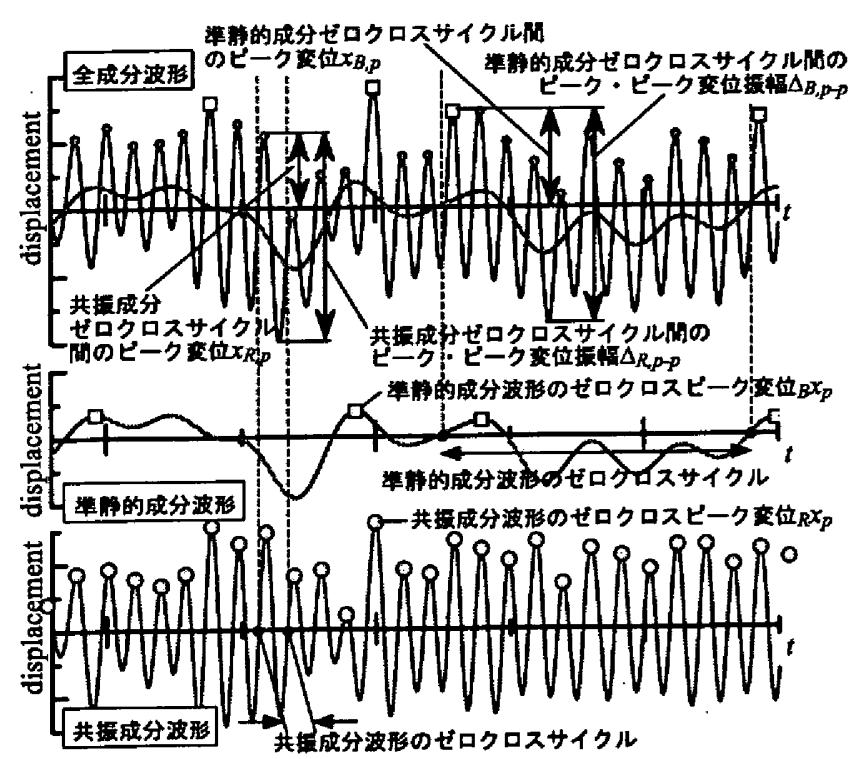

图 11 ピーク変位の定義 ( 図は極大值側のみを示して いる。極小値側も同様)

および共振成分波形のそれぞれのゼロクロスサイクル間の極值のう ち，最大の極大值および最小の極小值のものを灌静的成分波形およ び共振成分波形のゼロクロスピーク变位とし，それぞれ ${ }_{B} x_{p},{ }_{R} x_{p}$ とする。図 11 上段に示すように, 準静的成分および共振成分のゼ ロクロスサイクル間の全成分波形の極値のうち, 最大の極大値およ び最小の極小值を準静的成分ゼロクロスサイクル間のピーク変位 $x_{B, p}$, 共振成分ゼロクロスサイクル間のピーク変位 $x_{R, p}$ とする。さ らに，䇟り合う淮静的成分・共振成分それぞれのゼロクロスサイク ル間のピーク変位の差をそれぞれ準静的成分ゼロクロスサイクル間 のピーク・ピーク变位振幅 $\Delta_{B, p-p}$, 共振成分ゼロクロスサイクル間 のピーク・ピーク変位振幅 $\Delta_{R, p-p}$ とする。

弾塑性系の復元力特性は変位依存性をもつので，その応答評価や 応答性状の把握のためには変位の絶対量の情報が必要であり, 変位 の絶対量である準静的成分および共振成分それぞれのゼロクロス ピーク変位 $x_{B, p}, x_{R, p}$ の確率分布を知る必要がある。また，履歷吸 収エネルギーの評価のためには既報1が指摘するように，応答変位 の全振幅が必要であり, 準静的成分および共振成分それぞれのゼロ クロスサイクル間のピーク・ピーク変位振幅 $\Delta_{B, p-p}, \Delta_{R, p-p}$ の確率 分布を知る必要がある。以下に，準静的成分・共振成分それぞれの ゼロクロスサイクル間のピーク変位, ピーク・ピーク変位振幅 $x_{B, p}$, $x_{R, p}, \Delta_{B, p-p}, \Delta_{R, p-p}$ の確率密度関数の理論式を求める。

なお， $\xi$ を標準偏差 $(\mathrm{ms}) \sigma_{\xi}$ の確率変数とするとき, カ穴分布 $p_{\text {Gauss }}(\xi)$, レーリー分布 $p_{\text {Rayleigh }}(\xi)$ は, それぞれ以下の式で表さ れる。

$$
\begin{aligned}
& p_{\text {Gauss }}\left(\xi ; \sigma_{\xi}\right)=\frac{1}{\sqrt{2 \pi} \sigma_{\xi}} \exp \left(-\frac{\xi^{2}}{2 \sigma_{\xi}^{2}}\right) \\
& p_{\text {Rayleigh }}\left(\xi ; \sigma_{\xi}\right)=\frac{\xi}{\sigma_{\xi}^{2}} \exp \left(-\frac{\xi^{2}}{2 \sigma_{\xi}^{2}}\right)
\end{aligned}
$$

また，応答変位の全成分波形の $\operatorname{rms}$ (標準偏差) 值を $\sigma_{0 x}$, 準静的成 分波形および共振成分波形の $\mathrm{ms}$ 值をそれぞれ $\sigma_{B}, \sigma_{R x}$ とし， $\varepsilon$ は 外力のパワースペクトル密度の特性を表すパラメータ (表 1 参照) と する。
(1) 準静的成分ゼロクロスサイクル間のピーク变位 $x_{B, p}$

灌静的成分ゼロクロスサイクル間のピーク変位 $x_{B, p}$ は, 準静的 成分ゼロクロスサイクルが共振成分ゼロクロスサイクルより十分に 長いのて，共振成分ゼロクロスサイクル間の準静的成分の変動が小 さく，ほほ一定值であると仮定すれば，準静的成分波形のゼロクロ スピーク ${ }_{B} x_{p}$ 亡共振成分波形のゼロクロスピーク ${ }_{R} x_{p}$ の和とみなす ことが可能となる。また，準静的成分波形のゼロクロスピーク ${ }_{B} x_{p}$ は，広帯域性を考虑した定常カウス過程の極大値分布の理論式 ((3) 式)の正値部分と相似 ${ }^{4)}$ と仮定する。以上より， $x_{B, p}$ の確率密度関数 は次式により表される。

$$
p_{x_{B, p}}\left(x ; \sigma_{B}, \sigma_{R x}, \varepsilon\right)=\int_{0}^{\infty} \frac{1}{\phi} p_{w . b . p}\left(\xi ; \sigma_{B x}, \varepsilon\right) p_{R a y l e i g h}\left(x-\xi ; \sigma_{R x}\right) d \xi
$$

$$
\text { ただし, } \phi=\int_{0}^{\infty} p_{w . b . p}\left(\xi ; \sigma_{B^{x}}, \varepsilon\right) d \xi
$$

$p_{w . b . p}\left(\xi ; \sigma_{B x}, \varepsilon\right)$ は広带域性を考虑した定常ガウス過程の極大值分布 の理論式 ((3) 式) を示す。

(2) 共振成分ゼロクロスサイクル間のピーク変位 $x_{R, p}$

共振成分ゼロクロスサイクル間のピーク変位 $x_{R, p}$ は，共振成分 波形のゼロクロスピーク ${ }_{R} x_{p}$ とピーク発生時刻における準静的成分 変位 $x_{B}$ との和となり， ${ }_{R} x_{p}$ と $x_{B}$ は無相関に現れる，つまり独立し た事象であると仮定すれば， $x_{R, p}$ の確率密度関数は次式により表さ れる。

$$
p_{x_{R, p}}\left(x ; \sigma_{R x}, \sigma_{B} x\right)=\int_{0}^{\infty} p_{R a y l e i g h}\left(\xi ; \sigma_{R x}\right) p_{G a u s s}\left(x-\xi ; \sigma_{B^{x}}\right) d \xi
$$

(3) 準静的成分ゼロクロスサイクル間のビーク・ピーク变位 $\Delta_{B, p-p}$ 準静的成分ゼロクロスサイクル間のピーク・ピーク変位 $\Delta_{B, p-p}$ は，連続する正・負側の準静的成分ゼロクロスサイクル間のピーク 変位 $x_{B, p}(i), x_{B, p}(i+1)$ の差として表すことができる。

$$
\Delta_{B, p-p}(i)=\left|x_{B, p}(i+1)-x_{B, p}(i)\right|=\left|x_{B, p}(i+1)\right|+\left|x_{B, p}(i)\right|
$$

ここで, 準静的成分ゼロクロスサイクル間のピーク変位 $x_{B, p}$ が正・ 負側に無相関であると仮定すると， $\Delta_{B, p-p}$ の確率密度関数は $(10)$ 式を用いて次式により表される。

$$
\begin{aligned}
p_{\Delta_{B, p-p}}\left(x ; \sigma_{B^{x}}, \sigma_{R^{x}}, \varepsilon\right) & \\
& =\int_{0}^{\infty} p_{x_{B, p}}\left(\xi ; \sigma_{B^{x}}, \sigma_{R}, \varepsilon\right) p_{x_{B, p}}\left(x-\xi ; \sigma_{B^{x}}, \sigma_{R^{x}}, \varepsilon\right) d \xi
\end{aligned}
$$

(4) 共振成分ゼロクロスサイクル間のピーク・ピーク変位 $\Delta_{R, p-p}$ $i$ 番目の共振成分ゼロクロスサイクル間のピーク・ピーク変位 $\Delta_{R, p-p}(i)$ は，連続する正・負側の共振成分ゼロクロスサイクル間の ピーク変位 $x_{R, p}(i)$ と $x_{R, p}(i+1)$ の差として表すことができる。共振 成分ゼロクロスサイクル間のピーク変位 $x_{R, p}$ は共振成分波形のゼロ クロスピーク ${ }_{R} x_{p}$ とピーク発生時刻 $t_{i}$ における準静的成分波形の変 位 ${ }_{B} x$ との和なので,

$$
\Delta_{R, p-p}(i)=\left|\left[{ }_{R} x_{p}(i+1)+{ }_{B} x\left(t_{i+1}\right)\right]-\left[{ }_{R} x_{p}(i)+{ }_{B} x\left(t_{i}\right)\right]\right|
$$

準静的成分波形の変位 ${ }_{B} x$ は平均値ゼロのガウス過程に彷うので, $E\left[{ }_{B} x\left(t_{i+1}\right)-{ }_{B} x\left(t_{i}\right)\right]=0(E[]$ は期待值を表す) となり, 共振成分ゼロ クロスサイクル間のピーク・ピーク変位は次式で評価が可能となる。

$$
\Delta_{R, p-p}(i)=\left|{ }_{R} x_{p}(i+1)-{ }_{R} x_{p}(i)\right|
$$




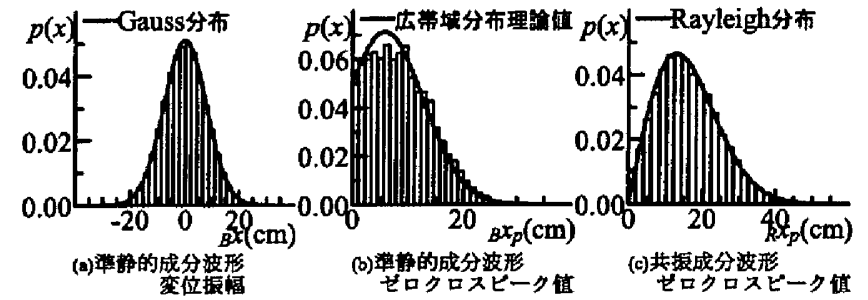

图 12 応答変位振幅とゼロクロスピーク変位の確率密度 関数 $\left(T_{0}=5 \mathrm{sec}, \zeta=0.02\right)$

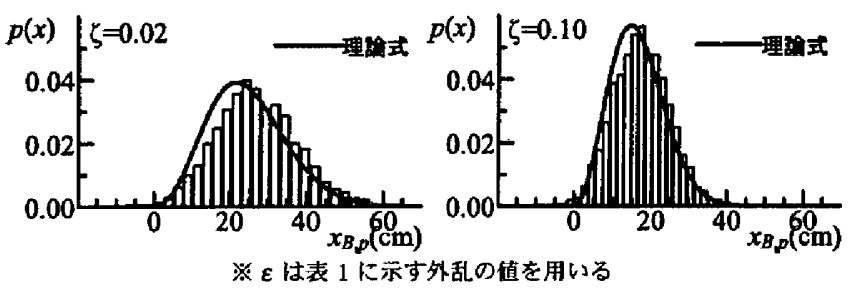

图 13 応答変位の隻静的成分ゼロクロスサイクル間の ピーク変位の確率密度関数 $\left(T_{0}=5 \mathrm{sec}\right)$
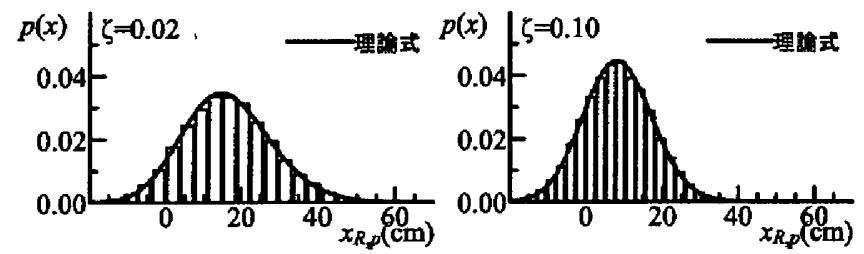

図 14 応答変位の共振成分ゼロクロスサイクル間の ピーク変位の確率密度関数 $\left(T_{0}=5 \mathrm{sec}\right)$

よって $\Delta_{R, p-p}(i)$ の期待值は，既報1に示されているように, ランダ 厶振動波形から部分サンプルを切り出し, 極大值の時刻を合すせて 重社合わせ自由振動波形を抽出する RD 法 (Random Decrement 法) ${ }^{7}$ ) の概念を応用して，次式で表すことができる。

$$
\begin{array}{ll}
E\left[\Delta_{R, p-p}(i)\right] & =(1+\beta)\left|{ }_{R} x_{p}(i)\right| \\
\text { ただし, } & \beta=\exp (-\zeta \cdot \pi) \\
& \zeta \text { は振動系の堿哀定数。 }
\end{array}
$$

共振成分ゼロクロスサイクル間のピーク・ピーク変位の確率密度関 数は， $\Delta_{R, p-p}=(1+\beta)_{R} x_{p}$ であり， $R_{p}$ は $\mathrm{rms}$ 值が $\sigma_{R}$ のレーリー 分布に従うので， $\mathrm{rms}$ 值が $(1+\beta) \sigma_{R}$ のレーリ一分布として次式で 表すことができる。

$$
\begin{aligned}
p_{\Delta_{R, p} p}\left(x ; \sigma_{R x}, \beta(\zeta)\right) & =p_{\text {Rayleigh }}\left(x,(1+\beta(\zeta)) \sigma_{R x}\right) \\
& =\frac{x}{(1+\beta)^{2} \sigma_{R x}^{2}} \exp \left(-\frac{x^{2}}{2(1+\beta)^{2} \sigma_{R^{x}}^{2}}\right)
\end{aligned}
$$

なお, $p_{w . b . p}(x)((3)$ 式) が愦差関数を含んでいるため, (10) 式の積 分を開くことが困難である。よって以下の検討では，ここで示した 応答変位の確率密度関数の基本式 (10), (11), (13),(18) 式を数值積分 し，それぞれの確率密度関数を求めている。

図 12 に応答变位の準静的成分波形の振幅と, 準静的成分波形お よび共振成分波形のゼロクロスピーク值の確率密度関数の例を示 す。各図中の曲線は，時刻歴解析結果の準静的成分, 共振成分それ ぞれの応答変位の $\mathrm{rms}$ 值と, 表 1 に示す変動風力の準静的成分のみ のパワースペクトル密度の特性を表すパラメータをを用いて求め た, カウス分布 ((8) 式), 広帯域ランダム過程の極大值分布の理論
式 ((3) 式)，レーリー分布 ((9) 式)をそれぞれ示す。図 12(a)，(c)に 示すように, 時刻歴応答解析結果による応答変位の潐静的成分波形 の変位振幅と共振成分波形のゼロクロスピーク変位の確率密度関数 は理論式とよく合っていることが確認できる。図 12(b)に示す準静 的成分波形のゼロクロスピーク変位の確率密度関数の理論值付, 時 刻歴店答解析結果に対して振幅の小さい部分に少し違いが見られる が，全体としてはよく適合している。図 13 に準静的成分ゼロクロ スサイクル間のピーク装位，図 14 に共振成分ゼロクロスサイクル 間のピーク変位の確率密度関数を示す。また，図 15 に準静的成分 ゼロクロスサイクル間のピーク・ピーク変位, 図 16 に共振成分ゼ ロクロスサイクル間のピーク・ピーク変位の確率密度関数を示す。 図中の曲線は，時刻歴店答解析による海静的成分，共振成分それぞ れの応答変位の標準偏差 $\sigma_{B x}, \sigma_{R x}$, および表 1 に示すパラメータ $\varepsilon$ を用いて求めた理論式 $((10),(11),(13),(18)$ 式) である。

図 13 の準静的成分ゼロクロスサイクル間のビーク変位, および 図 15 の準静的成分ゼロクロスサイクル間のピーク・ピーク変位の 確率密度関数では，提案する理論式は時刻麻応答解析結果よりやや 小さな振幅に極大値をもち，誤差を生じているが，よく適合してい る。 $\Delta_{B, p-p}$ は，(12) 式に示さ扎るよに互いに独立した 4 つの確

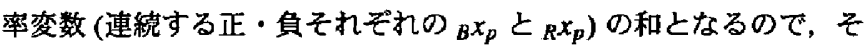
の確率密度関数は中心極限定理により, 平均值と分散がそれぞれ 4 つの変数の平均值と分散の和となる正規分布で近似可能と考えら れる。図 15 にこの近似式を一点鎖楾で示している。ここで示す近 似式は，4つの確率变数の結合が，(10) 式の準静的成分ゼロクロス ピークを任意に 2 つ取り出し，その和 (連䅴する正・負側の差はそ れぞれの絶対值の和)をとることに相当するので，次式で平均値 $\mu$ と分散 $\sigma^{2}$ を与えた正規分布である。

$$
\begin{aligned}
p_{\Delta_{B, p-p}}^{\prime}(x) & =\frac{1}{\sqrt{2 \pi} \sigma} \exp \left(-\frac{(x-\mu)^{2}}{2 \sigma^{2}}\right) \\
\mu & =2 \int_{0}^{\infty} x \cdot p_{x_{B, p}}\left(x ; \sigma_{B x}, \sigma_{R x}, \varepsilon\right) d x \\
\sigma^{2} & =2 \int_{0}^{\infty} x^{2} \cdot p_{x_{B, p}}\left(x ; \sigma_{B}, \sigma_{R} x, \varepsilon\right) d x-\frac{\mu^{2}}{2}
\end{aligned}
$$

近似式は (13) 式による予測式および時刻歴応答解析結果とよく合つ ている。近似式は正規分布関数であり，実用性が高く，取り扱いや すいので，以下の検討では近似式を用いる。

共振成分については, 図 14 よりゼロクロスピーク值分布の理論 式は応答解析結果とほぼ完全に一致すること，図 16 よりピーク・ ビーク值分布についても提案した理論式は応答解析結果とほぼ一致 することが確かめられる。ピーク・ピーク値分布のうち， $T_{0}=3 \mathrm{sec}$, $\zeta=0.10$ のケースでやや理論式の適合度が悪くなっている。これは, 共振成分之準静的成分は無相関であるものの, 振動系の固有周期が 短く，隇衰が大きくなると，相效的に準静的成分波形の振幅が大き くなり，共振成分ゼロクロスサイクル間のピーク変位において準静 的成分の振幅が支配的となる確率が增え, 共振成分と淮静的成分の 相関が見かけ上, 高くなり, (15) 式に誤差が生じることが原因と考 えられる。しかし，準静的成分の影響が大きく理論式に誤差が生じ る場合は，そもそも共振成分振幅が小さく，その影響が小さいと考 えられるため,ここでは隼静的成分は打ち消され (15) 式が成り立つ ものとして扱うこととする。

以上のように，本章では減衰弹性系の広带域ランダム応答時の応 答変位を準静的成分上共振成分に分離し，それぞれが広帯域ランダ 

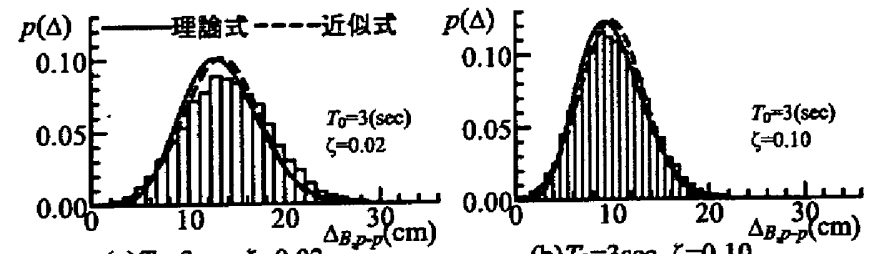

(a) $T_{0}=3 \mathrm{sec}, \zeta=0.02$
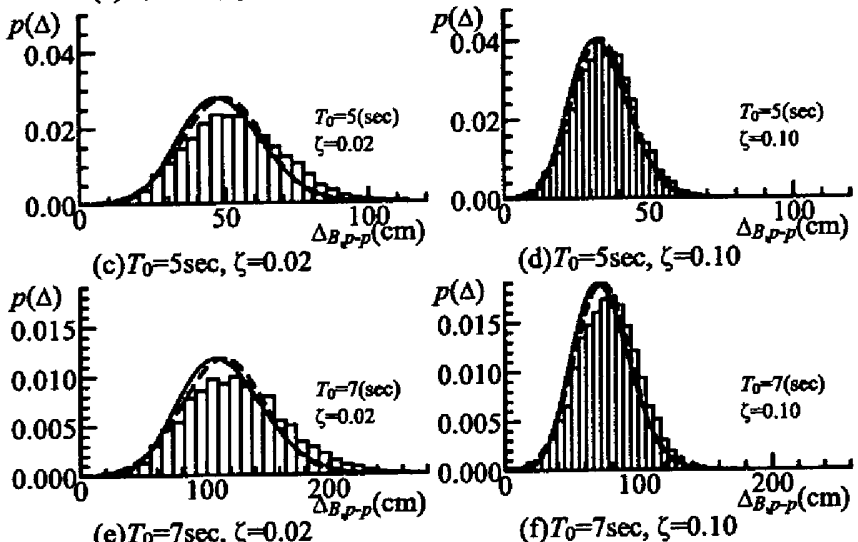

(e) $T_{0}=7 \mathrm{sec}, \zeta=0.02$

※ $\varepsilon$ は表 1 に示す外乱の值を用いる

图 15 応答変位の潐静的成分ゼロクロスサイクル間 のピーク・ピーク変位振幅の確率密度関数

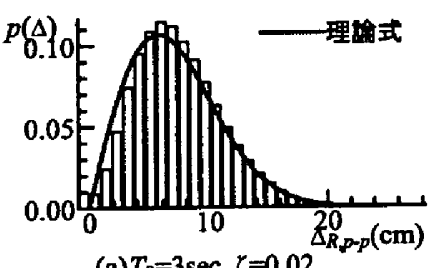

(a) $T_{0}=3 \mathrm{sec}, \zeta=0.02$

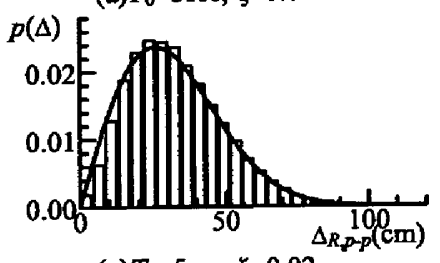

(c) $T_{0}=5 \mathrm{sec}, \zeta=0.02$

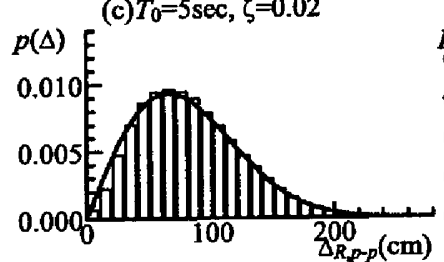

(e) $T_{0}=7 \mathrm{sec}, \zeta=0.02$

(e) $T_{0}=7 \mathrm{sec}$

$(\mathrm{f}) T_{0}=7 \mathrm{sec}, \zeta=0.10$
ロロスサイクル間の

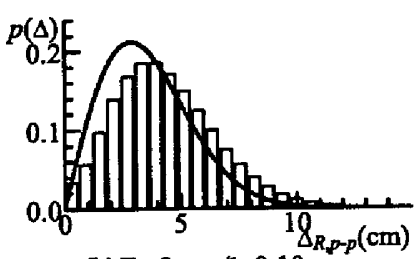

(b) $T_{0}=3 \mathrm{sec}, \zeta=0.10$

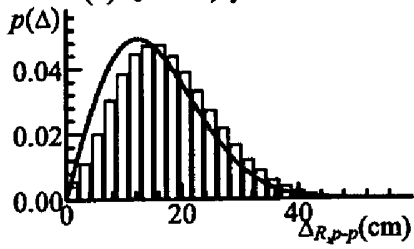

(d) $T_{0}=5 \mathrm{sec}, \zeta=0.10$

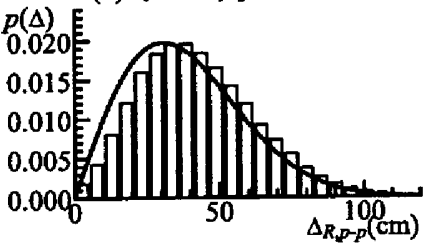

ピーク・ピーク変位振幅の確率密度関数

厶過程の極大值分布の理論式, 狭帯域ランダム応答の極大值分布の 理論式 (レーリー分布)に従うことを確認し，これらを組み合わせ て，準静的成分および共振成分のゼロクロスサイクル間のピーク変 位とピーク・ピーク変位振幅の確率密度関数の理論式を提案した。 また，提案式が時刻歴応答解析結果と概ね一致することを示し，提 案式の妥当性を確認した。

提案した理論式は, 準静的成分のみの外乱のパワースペクトル密 度の特性を表すパラメータ $\varepsilon$ と, 準静的成分および共振成分の応答 変位の標準偏差 $\sigma_{B}, \sigma_{R}$ と振動系の減衰定数 $\zeta$ ので表される関数 である。 $\varepsilon$ は変動風力の特性により求まり,また $\zeta$ は対象とする振
動系の特性であるから，これらは与条件として決定し， $\sigma_{B}, \sigma_{R x}$ は 確率統計的手法により評価できる応答量である。したがって，提案 式は，広带域ランダム応答する減衰弾性系のゼロクロスピーク変位 やピーク・ピーク変位振幅の確率密度関数を時刻歴店答解析を用い ることなく評価可能な理論式であり，実用性の高いものであるとい える。

\section{4. 弾塑性系の応答振幅の確率分布}

本章では，Bi-Linear 型復元力特性を有する 1 質点弾塑性系の時 刻歴風店答解析を行い，広帯域ランダム応答に対する検討を行う。 既報1),8)は，変動風力を受け定常ランダム振動している弾塑性系の エネルギー入力や店答変位・速度は，等価線形系で代表可能である こと，およぴ応答変位の確率分布は等価線形系の確率分布をもとに 上手く評価できることを示している。そこで本研究でも，弾塑性系 に対応する等価線形系の応答を利用して，弾塑性系の応答変位の確 率密度関数が予測可能であるかを検討する。また，提案した応答変 位振幅の確率密度関数の予測手法を用いて履歴吸収エネルキーを評 価し，時刻歴応答解析結果と比較することで提案手法の有効性を検 討する。

\section{1 時刻歴応答解析}

解析モテルは 2 章で説明したモデルとし，外力は 3 章で用いたも のと同じ，全長 $1638.4 \mathrm{sec}$ の模擬風力波形を 200 波用い，評価時間 $600 \mathrm{sec}$ の計 400 サンプルで評価を行う。構造減衰は初期剛性に対し て減衰定数 $\zeta=0.02$ とする。復元力特性は鉄骨造高層建物の履歷減 衰を想定し，图 17 に示す Normal Bi-Linear 型とする。弾性時の固 有周期 $T_{0}=5 \mathrm{sec}$ とし, 降伏後の剛性比 (第一 第二分枝剛性の比) $\alpha$, および降伏変形 $\delta$ をを解析パラメータとする。表 3 に解析パラメー 夕を示す。弾塑性系に対応する等価線形系のモテルは，既報1)と同 様に，エネルギー入力と等価線形系の吸収エネルギーの验合，及び 1 サイクルあたりのエネルギーの釣合から 1 サイクルあたりの弾塑 性系のひずみエネルギーの期待值と等価線形系の弾性ひずみエネル ギーが等しいという条件を与え, 次式より等価剛性 $k_{e q}$, 等価減衰 定数 $c_{e q}$ を算定して作成する。

$$
\begin{aligned}
k_{e q} & =\sum_{i=1}^{N}\left[\frac{1}{2} Q_{p i} \cdot x_{p i}\right] / \sum_{i=1}^{N}\left[\frac{1}{2} x_{p i}^{2}\right] \\
c_{e q} & =E_{\text {input }} / t_{0} \cdot \sigma_{\dot{x}}^{2}
\end{aligned}
$$

ここで， $x_{p i} ， Q_{p i} ， N$ は共振成分ゼロクロスサイクル間の最大 および最小変位点の変位 (ゼロクロスピーク変位), せ九断力お よび評価時間内のサイクル数。また， $t_{0}$ は評価時間， $E_{\text {input }}$ は 評価時間内の振動系へのエネルキー入力。

図 18 に解析に用いた等価線形系の等価剛性 $k_{e q}$ と等価減衰定数 $\zeta_{e q}$ を示す。ただし， $\zeta_{e q}=c_{e q} / 2 \sqrt{m \cdot k_{e q}}$ 。弾塑性系と等価線形系の 応答変位および応答速度の $\mathrm{ms}$ 值を図 19 に, エネルギー入力を図 20 に示す。エネルギ一入力は解析結果を評価時間 $(600 \mathrm{sec})$ で除し,

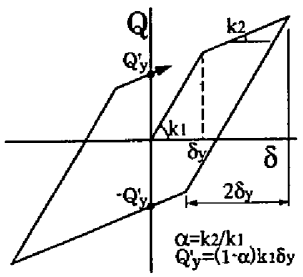

表 3 解析パラメータ

\begin{tabular}{c|l}
\hline$\alpha$ & $0.25,0.50,0.75$ \\
\hline$\delta_{y}(\mathrm{~cm})$ & $10,15,20,25,30$ \\
\hline
\end{tabular}




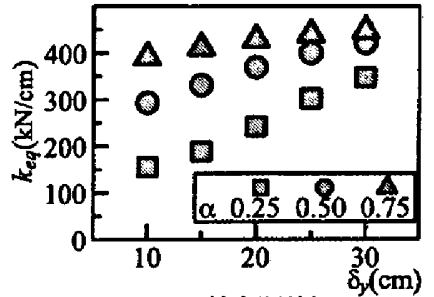

(a) 等価㣚性

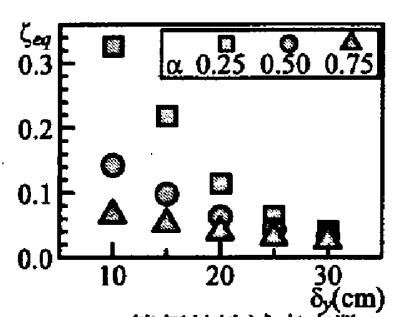

(b) 等価粘性減衰定数
园 18 等価線形系の等価剛性と等価減衰定数

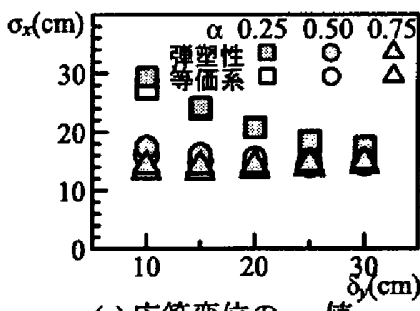

(a) 応答変位のrms值

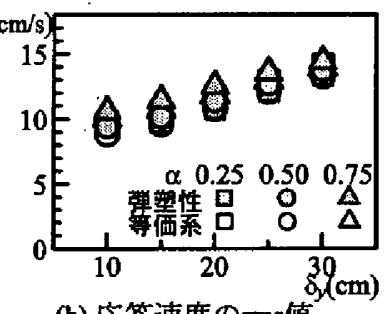

(b) 尔答速度のrms值
图 19 弹塑性系と等価線形系の㤁答変位 $\mathrm{rms}$ 值と応答 速度 rms 值

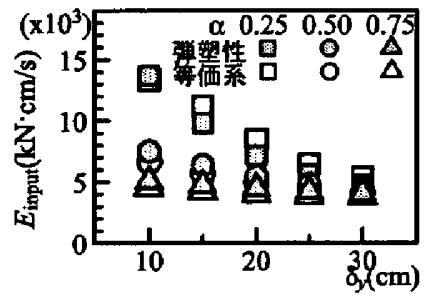

图 20 弾塑性系と等価線形系のエネルギー入力

単位時間あたりの平均值で示している。等価楾形系の応答值は, い ずれも弾塑性系の応答結果とよく一致しており，広带域性の変動風 力を受ける弾塑性系の応答は，(20)，(21) 式による等価線形系の応 答により代表可能であることが確かめられる。

\section{2 弾塑性系の応答变位確率密度閏数の予㨽}

(20) 式に示すように，弾望性系の等価線形化には 1 サイクルあた りのひずみエネルギ一等価の条件を用いているので, 弾望性系のゼ ロクロスピーク変位 $x_{i}$ と対応する等価楾形系のゼロクロスピーク 変位 eq $_{i}$ の関係は次式となる。

$\frac{1}{2} k_{e q} \cdot e q x_{i}^{2}=\left\{\begin{array}{l}\frac{1}{2} k_{1} \cdot x_{i}^{2} \quad\left(x_{i} \leq \delta_{y}\right) \\ \frac{1}{2} \alpha k_{1} \cdot x_{i}^{2}+(1-\alpha) k_{1} \cdot \delta_{y} \cdot x_{i}-\frac{1}{2}(1-\alpha) k_{1} \cdot \delta_{y}^{2} \quad\left(x_{i}>\delta_{y}\right)\end{array}\right.$

弾塑性系のゼロクロスピーク変位 $x_{i}$ の発生確率 $p\left(x_{i}\right) d x_{i}$ と対応する 等価線形系のゼロクロスピーク変位 $e q x_{i}$ の発生確率 $p^{\prime}\left(e q x_{i}\right) d_{e q} x_{i}$ が 等しいとおいて,

$$
p\left(x_{i}\right) d x_{i}=p^{\prime}\left({ }_{e q} x_{i}\right) d_{e q} x_{i}
$$

弾塑性系の $x_{i}$ の確率密度関数は (22) 式を $x_{i}$ について解き, 前章で 示した減衰弾性系の場合の準静的成分, 共振成分それぞれのゼロク ロスサイクル間のピーク変位, ピーク・ピーク変位振幅の確率密度 関数を $\left.p^{\prime}{ }_{(e q} x_{i}\right)$ として，(23) 式に代入して求めることができる。た だし，共振成分ゼロクロスサイクル間のピーク変位は，準静的成分 により変位点付近を中心に共振成分の振幅が生じるので, 見かけの
等価剛性を下式で評価する。

$$
\begin{gathered}
k_{e q, R}=\sum_{i=1}^{N}\left[\frac{1}{2} Q_{p i}^{\prime} \cdot x_{p i}^{\prime}\right] / \sum_{i=1}^{N}\left[\frac{1}{2} x_{p i}^{\prime 2}\right] \\
\text { たた゚し, } Q_{p i}^{\prime}=\left(Q_{p i+1}-Q_{p i}\right) / 2 \\
x_{p i}^{\prime}=\left(x_{p i+1}-x_{p i}\right) / 2
\end{gathered}
$$

ここで, $x_{p i}, x_{p i+1}, Q_{p i}, Q_{p i+1}$ は共振成分ゼロクロスサイクル 間の連䌇する (i 番目, (i+1) 番目の) 最大および最小変位点の変 位 (ゼロクロスピーク変位), せん断力および $N$ は評価時間内の サイクル数。

図 21 に各ケースの等価剛性 $k_{\text {eq,R }}$ を示す

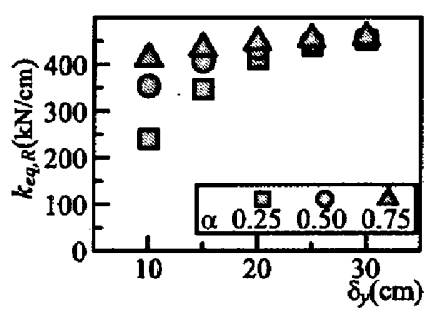

图 21 共振成分ゼロクロスピークによる等価剛性

以下に前章の (1) （4) に対応させて準静的成分および共振成分そ れぞれのゼロクロスサイクル間のピーク変位とピーク・ピーク変位 の確率密度関数の評価方法を示す。

(1) 準静的成分ゼロクロスサイクル間のピーク变位 $x_{B, p}$

忘答変位の準静的成分波形の $\mathrm{rms}$ 值を与え, (10) 式により ${ }_{e q} p_{x_{B, p}}(x)$ を求める。これは対応する等価線形系の確率密度関数 に相当するため，記号に添字 ${ }_{e q}$ をつけている。(23) 式の $p^{\prime}\left({ }_{e q} x_{i}\right)$ に ${ }_{e q} p_{x_{B, p}}, e_{e q} p_{x_{R, p}}$ を代入し, 弾塑性系の淮静的成分ゼロクロスサイク ル間のピーク変位の確率密度関数 $p_{x_{B, p}}$ を得る。

(2) 共振成分ゼロクロスサイクル間のビーク变位 $x_{R, p}$

$x_{B, p}$ と同様に，応答変位の共振成分波形の $\mathrm{rms}$ 值を与え，(11）式 により $e_{e q} p_{R, p}(x)$;を求め, 得られた ${ }_{e q} p_{x_{R, p}}$ を(23) 式の $p^{\prime}\left({ }_{e q} x_{i}\right)$ に代 入し，弹塑性系の共振成分ゼロクロスサイクル間のピーク変位の確 率密度関数 $p_{x_{R, p}}$ を得る。

(3) 準静的成分ぜロクロスサイクル間のピーク・ピーク変位 $\Delta_{B, p-p}$

前章で述べたように，準静的成分ゼロクロスサイクル間のピー ク・ピーク変位は, 中心極限定理より正規分布に収束すると考えら れる。これは, 弾塑性系の場合にもそれぞれが独立な確率変数であ るので，成立すると予想される。そこで，前章にならい，淮静的成 分ゼロクロスピーク変位の確率密度関数 (弾塑性系に変換したもの) を(19) 式に代入し，正規分布を用いて準静的成分ゼロクロスサイク ル間のビーク・ピーク変位の確率密度関数 $p_{\Delta_{B, p-p}}$ を評価する。 (4) 共振成分ゼロクロスサイクル間のピーク・ピーク变位 $\Delta_{R, p-p}$

共振成分ゼロクロスサイクル間のピーク・ピーク変位の確率密度

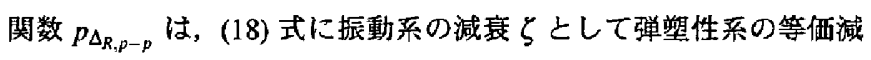
衰を用いて評価する。

図 22 に時刻歴応答解析結果と理論式による淮静的成分ゼロクロ スサイクル間のピーク変位の確率密度関数の比較を示す。(20) 式に よる等価剛性 $k_{e q}$ を用いた予測式は $\alpha=0.25 \sim 0.50, \delta,=10 \mathrm{~cm}$ の 場合に時刻歴応答解析結果との誤差が大きいが，(24) 式による等洒 剛性 $k_{e q, R}$ を用いた理論値 (図中の一点鎖線) は, すべてのケースで 時刻歴応答解析結果とよく合っている。なお，図中の波線で示す等 


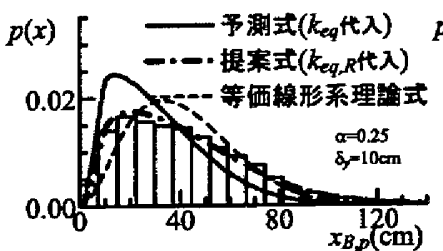

(a) $\alpha=0.25, \delta_{\gamma}=10 \mathrm{~cm}$

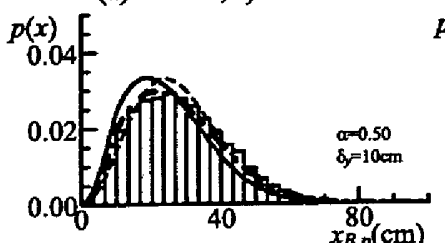

(c) $\alpha=0.50, \delta_{y}=10 \mathrm{~cm}^{x}$

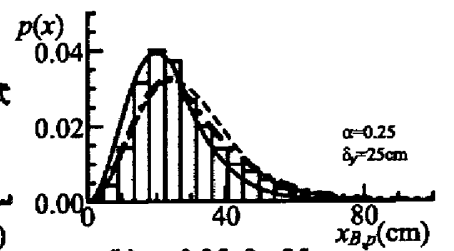

(b) $\alpha=0.25, \delta_{y}=25 \mathrm{~cm}$

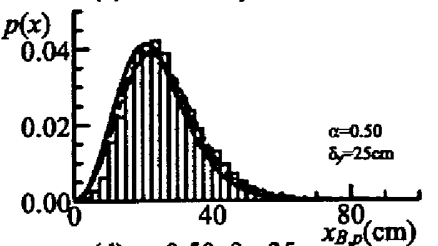

(d) $\alpha=0.50, \delta_{y}=25 \mathrm{~cm}^{x}$

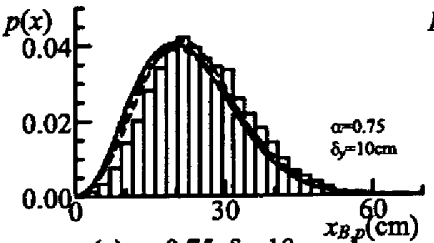

(e) $\alpha=0.75, \delta,=10 \mathrm{~cm}$

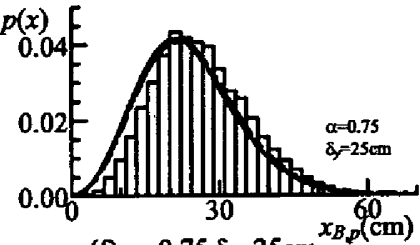

(f) $\alpha=0.75, \delta_{y}=25 \mathrm{~cm}$

图 22 準静的成分ゼロクロスサイクル間のピーク変位の 確率密度関数

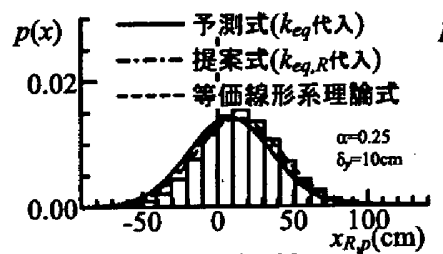

(a) $\alpha=0.25, \delta_{y}=10 \mathrm{~cm}$

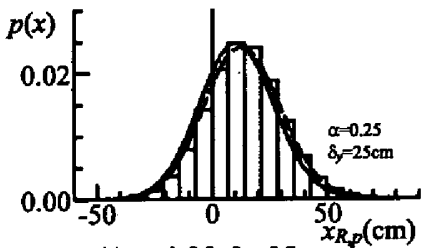

(b) $\alpha=0.25, \delta_{y}=25 \mathrm{~cm}$

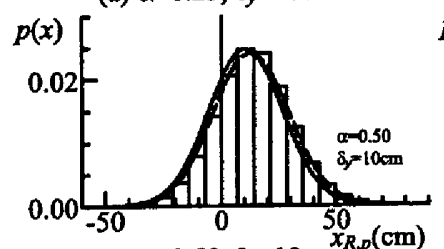

(c) $\alpha=0.50, \delta_{y}=10 \mathrm{~cm}$

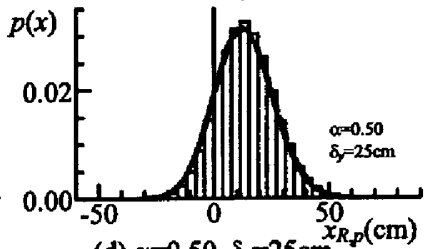

(d) $\alpha=0.50, \delta_{j}=25 \mathrm{~cm}$

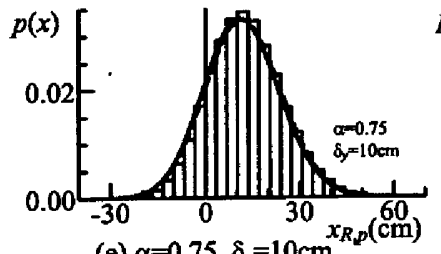

(e) $\alpha=0.75, \delta_{y}=10 \mathrm{~cm}$

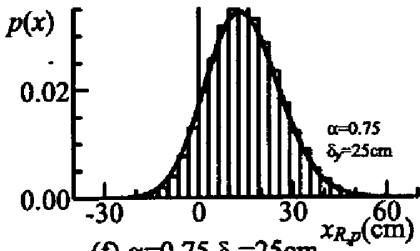

(f) $\alpha=0.75, \delta_{y}=25 \mathrm{~cm}^{\alpha}$

图 23 共振成分ゼロクロスサイクル間のピーク変位の 確率密度関数

価線形系理論式は応答変位の $\sigma_{B x}$ を $(10)$ 式に代入して求めた, 弾塑 性系への変換前の確率密度関数 ${ }_{e q} p_{x_{B, p}}$ である。図 23 に時刻歴忘答 解析結果と理論式による共振成分ゼロクロスサイクル間のピーク変 位の確率密度関数の比較を示す。確率密度関数の理墖式は $k_{e q}, k_{e q, R}$ のいずれを用いても時刻歴応答解析結果とよく合っている。図中の 波線で示す等価線形系理論式は応答変位の $\sigma_{R}$ を(11) 式に代入して 求めた ${ }_{e q} p_{x_{R, p}}$ である。図 24 に準静的成分ゼロクロスサイクル間の ピーク・ピーク変位振幅の確率密度関数を示す。提案式は, やや適 合度が悪い部分もあるが, 全体としては時刻歴応答解析結果とよい 対応を示している。図 25 に共振成分ゼロクロスサイクル間のピー ク・ピーク変位振幅の確率密度関数を示す。提案式は， $\alpha \cdot \delta_{y} か ゙$ 小

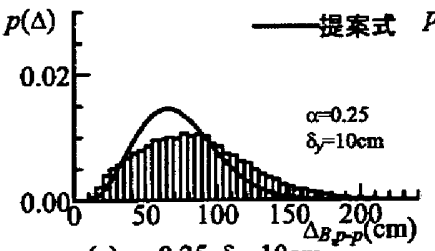

(a) $\alpha=0.25, \delta_{y}=10 \mathrm{~cm}$

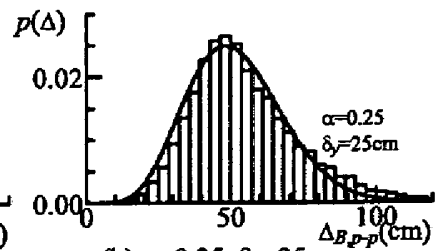

(b) $\alpha=0.25, \delta_{y}=25 \mathrm{~cm}$

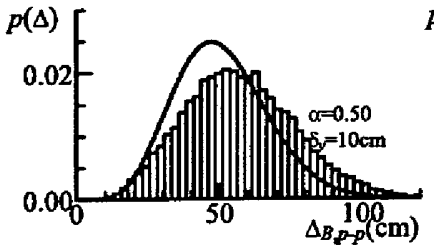

(c) $\alpha=0.50, \delta_{y}=10 \mathrm{~cm}$

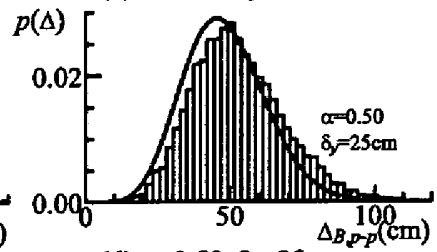

(d) $\alpha=0.50, \delta_{y}=25 \mathrm{~cm}$

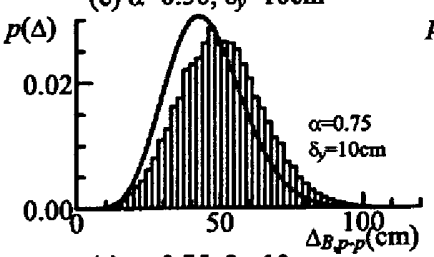

(e) $\alpha=0.75, \delta_{y}=10 \mathrm{~cm}$

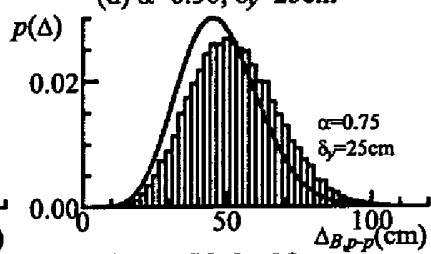

(f) $\alpha=0.75, \delta_{y}=25 \mathrm{~cm}$

図 24 準静的成分ゼロクロスサイクル間のピークピーク変位振幅 の確率密度関数

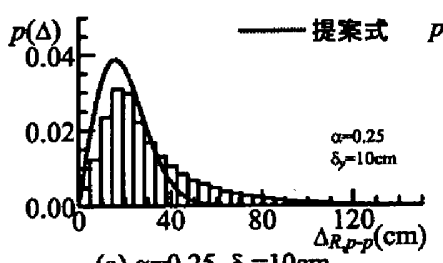

(a) $\alpha=0.25, \delta_{y}=10 \mathrm{~cm}$

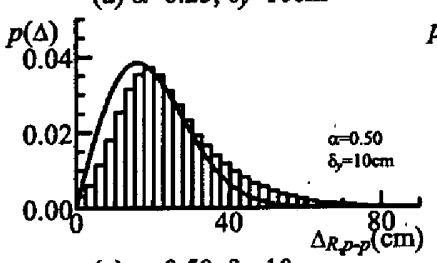

(c) $\alpha=0.50, \delta_{y}=10 \mathrm{~cm}$

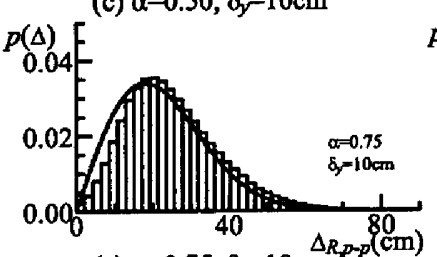

(e) $\alpha=0.75, \delta_{y}=10 \mathrm{~cm}$

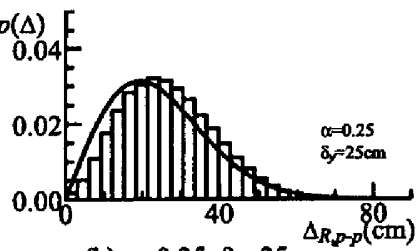

(b) $\alpha=0.25, \delta_{y}=25 \mathrm{~cm}$

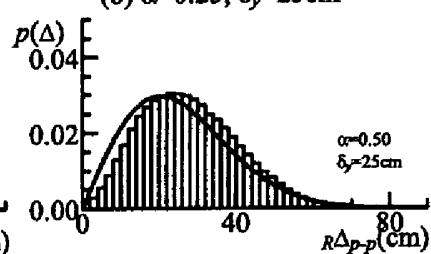

(d) $\alpha=0.50, \delta_{y}=25 \mathrm{~cm}$

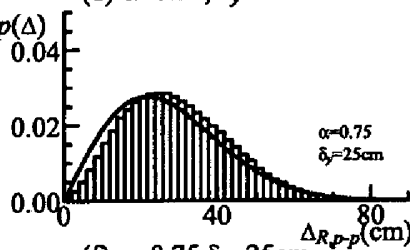

(f) $\alpha=0.75, \delta_{y}=25 \mathrm{~cm}$

图 25 共振成分ゼロクロスサイクル間のピークピーク変位振幅の 確率密度関数

さい場合に適合度が悪くなっているが，全体としては時刻歴応答解 析結果とよく合っている。 $\alpha \cdot \delta_{y}$ が小さい場合に適合度が悪くなる のは，前章でも述べたように，塑性化の度合いが大きく，等価減衰 が大きくなる影響と考えられる。

次に，提案した応答変位振幅の確率密度関数の予測式を用いて広 帯域性の変動風力を受ける弾塑性系の履歴吸収エネルギーの評価を 行い，時刻歴応答解析結果と比較する。

予涮式には準静的成分亡共振成分それぞれのゼロクロスサイクル 間のピーク変位を $(24)$ 式による $k_{e q, R}$ を用いて評価し, 共振成分と 準静的成分それぞれのゼロクロスサイクル間のピーク・ピーク変位 には本章の (3),(4) 項で述べた方法を適用する。図26に広帯域性の 変動風力を受ける弾塑性系の応答変位波形と履歴ループの概念図 


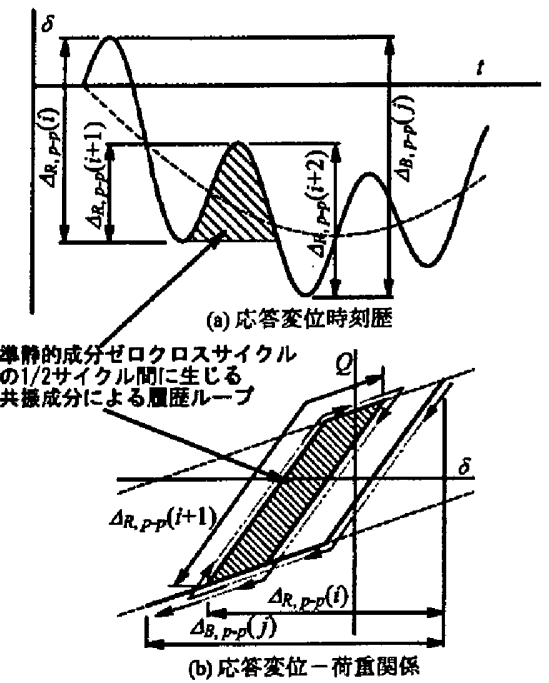

图 26 履歴吸収エネルギーに寄与する準静的成分と 共振成分による变位の関係

を示す。すでに示したように，広帯域性の変動風力を受ける弾塑性 系の応答は，準静的成分による周期の長い変動と共振成分に上る周 期の短い変動の和として表現できる。図 26 は淮静的成分の $1 / 2$ サ イクル間に共振成分による変動が 1 サイクル生じる様子を示して いる。この時, 準静的成分と共振成分それぞれのゼロクロスサイク ル間のピーク・ピーク変位振幅の関係を見ると，準静的成分による 変位と同じ力向となる $(i),(i+2)$ 番目の共振成分ゼロクロスサイク ル間のピーク・ピーク变位には，準静的成分ゼロクロスサイクル間 のピーク・ピーク変位と重複する部分が生じている。よって, 準静 的成分と共振成分のゼロクロスサイクル間のピーク・ピーク変位か ら，それらの和として履歴吸収エネルギーを評価すると，ピーク。 ピーク変位の重複により履歴吸収エネルギーを過大に評洒すること になる。しかし，淮静的成分による 1 方向の変位振幅の間の共振 成分による履歴ループは，共振成分によるピーク・ピーク変位振幅 $\Delta_{R, p-p}(i)$ の直後に現れる準静的成分による変位とは逆向きのピー ク・ピーク変位振幅 $\Delta_{R, p-p}(i+1)$ の大きさをもつループとなってい る。ここで, $i, i+1$ 番目の $\Delta_{R, p-p}$ は次式となる。

$$
\begin{aligned}
\Delta_{R, p-p}(i) & =||_{R} x_{p}(i+1)--_{R} x_{p}(i) \mid \quad \text { および } \\
\Delta_{R, p-p}(i+1) & =||_{R} x_{p}(i+2)-{ }_{R} x_{p}(i+1) \mid
\end{aligned}
$$

$k$ 番目の ${ }_{R} x_{p}$ が生じた時，直後に生じる $k+1$ 番目の ${ }_{R} x_{p}$ の期待値 は，(16) 式と同様に RD 法7)の概念を応用し次式で表わされる。

$$
E\left[{ }_{R} x_{p}(k+1)\right]=-\beta \cdot_{R} x_{p}(k)
$$

これを(25) 式に代入すると，

$$
\begin{aligned}
E\left[\Delta_{R, p-p}(i+1)\right] & =\left|-\beta \cdot \cdot_{R} x_{p}(i+1)+\beta \cdot \cdot_{R} x_{p}(i)\right| \\
& =\beta \cdot \Delta_{R, p-p}(i)
\end{aligned}
$$

したがって履歴吸収エネルギーの単位時間当たりの期待値 $\overline{W_{p}}$ は, 準静的成分ゼロクロスサイクル間のピーク・ピーク変位 $\Delta_{B, p-p}$ と, $\Delta_{B, p-p}$ によるループと重複しない共振成分による展歴ループとし $\tau$, 共振成分ゼロクロスサイクル間のピーク・ピーク変位 $\Delta_{R, p-p}$ に 対して $\beta \cdot \Delta_{R, p-p}$ から, それぞれの塑性変形を評価して, 次式で表
すことができる。

$$
\begin{aligned}
\overline{W_{p}} & =v_{B} \cdot 1 \cdot B W_{p}+v_{R} \cdot 1 \cdot R W_{p} \\
{ }_{1 \cdot B} W_{p} & =2 Q_{y}^{\prime} \cdot \int_{2 \delta_{\delta}}^{\infty}\left(p_{\Delta_{B, p-p}}(x) \cdot x-2 \delta_{y}\right) d x \\
{ }_{1 \cdot R} W_{p} & =2 Q_{y}^{\prime} \cdot \int_{2 \delta_{y} / \beta}^{\infty}\left(p_{\Delta_{R, p-p}}(x) \cdot \beta \cdot x-2 \delta_{y}\right) d x
\end{aligned}
$$

ただし， $Q_{y}^{\prime}=(1-\alpha) k_{1} \delta_{y}$ 。また，1,B $W_{p},{ }_{1 \cdot R} W_{p}$ は準静的成分 または共振成分ゼロクロスサイクル間のピーク・ピーク変位に よる 1 サイクルあたりの履歴吸収エネルギーの期待值, $v_{B}, v_{R}$ は準静的成分および共振成分ゼロクロッシング数。

図 27 に準静的成分と共振成分それぞれのゼロクロスサイクル間の ピーク・ピーク変位の確率密度関数の予測式を用いて評価した履歴 吸収エネルギーを時刻歴応答解析結果と比較して示す。なお， $v_{B}, v_{R}$ は時刻歴応答解析結果による準静的成分, 共振成分それぞれのゼロ クロッシング数を用いた。図 27 から, 時刻歴応答解析結果と応答 解析結果の振幅の確率密度関数から (28) 式により評価した履歴吸 収エネルギ一はよく対态しており，(28) 式による評価が妥当である ことが確かめられる。また，準静的成分・共振成分のピーク・ピー ク変位振幅の確率密度関数の提案式から (28) 式により評価した履 歴吸収エネルギーは，時刻歴応答解析結果と良く対応しており，提 案式の妥当性が示された。
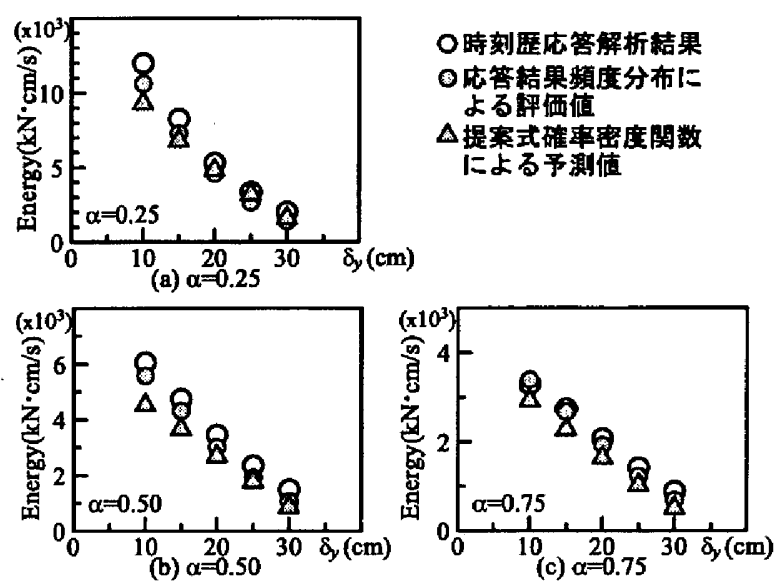

图 27 ピークピーク変位振帽の確率密度関数による 履歴吸収エネルギーの予測

\section{5. 結び}

定常ランダム振動の極值分布の理論解を基に，平均値がゼロの広 带域性の変動風力を受ける弾塑性系の応答変位振幅の確率密度関数 を導き，その有効性について検討を行い，以下の結論を得た。

1. 広带域ランダム応答する減衰弾性系の応答変位を準静的成分と 共振成分に分離し，広帯域・狭帯域ランダム過程の極大值分布 の理論式を基に準静的成分および共振成分のゼロクロスサイク ル間の最大值分布 (ゼロクロスピーク值分布) とピーク・ピーク 值分布の確率密度関数の理論式を提案した。また，提案式が時 刻楚応答解析結果と概ね一致することを示し，提案式の妥当性 を確認した。

2. 減衰弾性系の応答変位の確率密度関数の予測式を弾塑性系に 拡張し，提案式が時刻歴応答解析結果と概ね一致することを示 した。 
3. 提案した予測式を用いて，広帯域性の変動風力を受ける 1 質点 弾塑性系の履歴吸収エネルギーの評便を行い, 予湘值が時刻歴 応答解析結果とよく一致することを示し，提案手法の有効性を 確認した。

提案した理論式は，外乱のパワースペクトル密度と，染静的成分お よび共振成分の応答変位の標準偏差と振動系の構造特性のみで表さ れる関数であり，広帯域ランダム応答する構造物のゼロクロスピー ク值分布やピーク・ピーク值分布を時刻歴応答解析を用いることな く評価可能な理諭式であり，実用性の高いものであると考える。

\section{考文献}

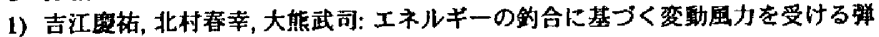
望性棈造物の応答予测手法, 日本建策学会满造系諭文集, 第 589 号, pp. 59-66, 20053
2) S.H. Crandall, W.D. Mark, 周村秀勇訳: 㭖栈技術者のためのランダム振動, コロ 才社, 1975

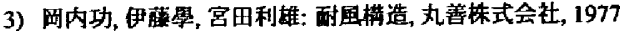

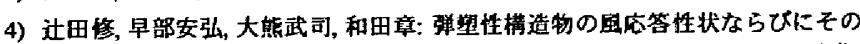
予測手法に関する研究その 2 蚛方向振動の場合, 日本建策学会措造系論文集, 第 485 号, pp. 25-34, 1996.7

5) 日本建策学会: 建筑物荷重指針 ·同解説 (2004), 2004

6) 星谷勝: 確毫論手法による满造挆析, 鹿島出版会, 1973

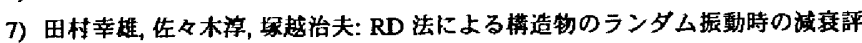
価, 日本建策学会構造系諭文啹告集，第 454 号, pp. 29-38, 1993.12

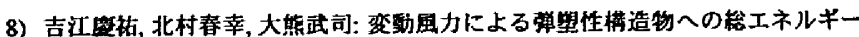
入力に関する研究, 日本建策学会满造系諭文集, 第 572 号, pp. 31-38, 2003.10

（2005年10月10日原稿受理，2006年 2 月 9 日操用決定） 